\title{
Deslocamentos de fronteiras: percurso e produção musical de Gonzagão e Gonzaguinha ${ }^{1}$
}

\author{
Desplazamientos de fronteras: recorrido y producción musical de \\ Gonzagão y Gonzaguinha
}

\author{
Border dislocations: the trajectories and musical production of \\ Gonzagão and Gonzaguinha
}

Cláudia Pereira Vasconcelos ${ }^{2}$

\begin{abstract}
Resumo
O presente trabalho pretende discutir de que forma os percursos, permeados por diversas fronteiras que hierarquizam saberes, poderes e enunciados, interferiram na produção artística de dois músicos brasileiros, oriundos de lugares historicamente marginalizados no Brasil, a saber: Luiz Gonzaga do Nascimento (conhecido como Gonzagão), vindo do sertão de Pernambuco para ganhar as paradas de sucesso no Rio de Janeiro nos anos 1940/50 e Luiz Gonzaga do Nascimento Júnior (o Gonzaguinha), nascido no Morro de São Carlos/Rio de Janeiro, que alcançou grande sucesso entre as décadas de 1970/80. Interessa investigar quais estratégias e táticas cada um desses artistas utilizou para driblar as fronteiras que separam o "centro" e a "periferia" e alcançar o cobiçado panteão da Música Popular Brasileira. Tal discussão é parte da pesquisa de doutorado em Estudos de Cultura (em curso) intitulada: Deslocamentos de fronteiras: percurso e produção musical de Gonzagão e Gonzaguinha na construção das brasilidades, realizada na Universidade de Lisboa. Para compreender a relação entre música, percurso e identidade, assim como para pensar a fronteira como construção simbólica serão tomados como aportes teóricos conceitos e reflexões oriundos do pensamento pós-colonial e decolonial.
\end{abstract}

Palavras-Chave: Fronteiras Culturais; Gonzagão e Gonzaguinha; Música e Identidades; Percursos Decoloniais.

\section{Resumen}

El presente trabajo busca comprender de qué forma los caminhos, impregnados por diversas fronteras que jerarquizan saberes, poderes y enunciados, han interferido en la producción artística de dos músicos brasileños, oriundos de lugares históricamente marginados en Brasil, a saber: Luiz Gonzaga do Nascimento (conocido como Gonzagão) originario del medio rural de Pernambuco, que alcanzó grande éxito en la escena musical de Rio de Janeiro en los años 1940/50 y Luiz Gonzaga do Nascimento Júnior (apodado Gonzaguinha) nacido en el Morro de São Carlos/Rio de Janeiro, que tuvo gran éxito entre las décadas de 1970/80. Interesa pensar qué estrategias y tácticas cada uno utilizó para romper las fronteras que separan el "centro y la periferia" y alcanzar el deseado panteón de la Música Popular Brasileña. Este trabajo es parte del proyecto de investigación desarrollado en el programa de doctorado en Estudios de Cultura (ora en curso) titulado Desplazamientos de fronteras: recorrido y producción musical de Gonzagão y Gonzaguinha en la construcción de las brasilidades, cumplido en la Universidade de Lisboa. Con el objetivo de comprender la relación entre música, caminos recorridos e identidad, asi como pensar el concepto de frontera como construcción simbólica, serán tomados como aportes teóricos conceptos y reflexiones oriundos del pensamiento poscolonial y decolonial.

Palabras-claves: Fronteras Culturales; Gonzagão y Gonzaguinha; Música y Identidades; Recorridos Decoloniales.

\section{Abstract}

\footnotetext{
${ }^{1}$ Artigo apresentado no Simpósio Temático 05 - "Fronteiras Culturais em Contextos Epistêmicos Descoloniais II" durante o II Seminário Latino-Americano de Estudos em Cultura - SEMLACult em Foz do Iguaçu/PR, Brasil, 2018.

${ }^{2}$ Doutoranda em Estudos de Cultura pela Universidade de Lisboa e professora de História da Universidade Estadual da Bahia - UNEB; Salvador, Bahia, Brasil; claudia.culturas@gmail.com
} 
This work aims to discuss the manner in which the trajectories, permeated by diverse frontiers that hierarchize knowledge, power and voice, interfered in the artistic production of two Brazilian musicians, originating from historically marginalized places in Brazil: Luiz Gonzaga do Nascimento (Gonzagão), coming from the semi-arid region of Pernambuco and gaining great success in Rio de Janeiro in the 1940s and 50s and Luiz Gonzaga do Nascimento Júnior (Gonzaguinha), born in Morro de São Carlos in Rio de Janeiro and achieving great success during the 1970s and 80s. Of particular interest is investigating which strategies and tactics each of these artists used to circumvent the frontiers that separate the "center" and the "periphery" and reach the coveted pantheon of Brazilian Popular Music. This discussion is part of doctoral research in Cultural Studies (in progress) titled Border dislocations: the trajectories and musical production of Gonzagão and Gonzaguinha in the construction of Brasilidades, carried out at the University of Lisbon. To understand the relationship between music, trajectory and identity, as well as to think about the concept of frontier as a symbolic construction, concepts and reflections coming from postcolonial and decolonial thought will be used as a theoretical basis.

Key-Words: Cultural Frontiers; Gonzagão and Gonzaguinha; Music and Identities; Decolonial Trajectories.

\section{Introdução}

No Brasil, a música ocupa um lugar muito importante na história sociocultural, pois que a mesma foi e é produzida a partir de encontros, misturas, fusões entre etnias, regiões, classes sociais e religiões, formando assim um verdadeiro mosaico do que se projetou como brasilidade ou cultura brasileira. Segundo Marcos Napolitano (2005), a música popular, tornou-se, especialmente no século XX, uma espécie de mediadora de valores culturais diversos, tradutora dos nossos dilemas sociais e termômetro das nossas sociabilidades e sensibilidades coletivas mais profundas.

A canção popular (verso e música) é uma expressão artística com grande poder de comunicação que alcança as mais diversas camadas sociais, devendo ser vista como uma rica fonte para compreender diferentes realidades que historicamente estiveram à margem da história oficial. Por isso, o estudo desse importante e complexo documento estético possibilita-nos conhecer a própria História do Brasil em seus diversos aspectos.

Nesse mosaico musical que é o Brasil encontramos peças fundamentais que nos ajudam a compreender a formação da nossa sociedade, bem como os processos de construção da identidade nacional, permeada por discursos ora complementares, ora conflitantes. É nesse cenário de encontros e desencontros que esse trabalho propõe adentrar o universo musical de dois grandes artistas brasileiros que, com suas canções, poéticas e performances, traduziram diferentes faces de um mesmo Brasil. São eles: Luiz Gonzaga do Nascimento, o popular Gonzagão e seu filho Luiz Gonzaga do Nascimento Junior, o Gonzaguinha que, em diferentes períodos da história do Brasil, tornaram-se grandes nomes da Música Popular Brasileira, imprimindo, cada um a seu modo, uma influência marcante no cenário nacional através de suas canções. 
O presente texto é parte de uma pesquisa de doutorado em curso, no âmbito do Programa de Pós-Graduação em Estudos de Cultura, realizada na Universidade de Lisboa em regime de co-tutela com o Programa Multidisciplinar de Pós-Graduação em Cultura e Sociedade da UFBA. O estudo que tem como título: Deslocamentos de fronteiras: percurso e produção musical de Gonzagão e Gonzaguinha na construção das brasilidades, visa discutir as obras dos artistas citados, a partir de 03 questões principais:

1. Considerando os percursos de vida e os deslocamentos realizados pelos sujeitos estudados para alcançar o sucesso, que táticas e/ou estratégias cada um utilizou para driblar as fronteiras que separam "centro" e "periferia"?

2. Suas obras e suas presenças podem ser consideradas representativas na emergência de dizeres e sentidos que vão na contramão dos discursos oficiais de brasilidade? Podem ser lidas como discursos insubordinados?

3. Como o elo entre pai e filho famosos aparece nas suas obras?

Para justificar a importância das questões discutidas nesse texto é importante dizer que Luiz Gonzaga, o pai de Gonzaguinha, nasceu no sertão de Pernambuco, região Nordeste, um território geográfico e político insistentemente identificado no imaginário nacional como o lugar do atraso, da seca, portanto, da pobreza material, do analfabetismo, da religiosidade popular exacerbada e de um tipo de violência associado ao mundo rural (cangaço e luta pela posse de terras). Apesar de originário desse território-representação do atávico por excelência e de pertencer a uma família pobre e negra, Luiz Gonzaga se consagrou, a partir dos anos 1940/50, como o "Rei do Baião". Ficou conhecido em todo território nacional cantando e contando esse Brasil sertanejo, concebido para ser esquecido ou estigmatizado pelo projeto de modernização da nação. Sua presença no imaginário nacional até os dias de hoje, especialmente no período das festas juninas, ainda é muito marcante, tendo visibilidade também em âmbito mundial.

De um outro lado da cena cultural, cerca de trinta anos depois, Luiz Gonzaga do Nascimento Júnior, o Gonzaguinha, alcança grande sucesso tornando-se um dos compositores mais prestigiados e requisitados no cenário nacional entre os anos 1970 e 1990. Apesar de chegar ao topo do sucesso no final da década de 1970 e ter nascido na moderna cidade do Rio de Janeiro (região Sudeste), Gonzaguinha também pode ser pensado como um sujeito que sai de outro território considerado marginal e consegue, através da sua música, obter visibilidade no cenário cultural brasileiro. Nascido e criado no Morro de São Carlos (Estácio), área periférica do Rio, atualmente denominada de "favela", de onde, segundo os discursos oficiais 
de uma política de segurança colonialista e elitista, advém uma população "perigosa". Cresceu na casa dos padrinhos em um espaço de escassez e ausências em vários aspectos. Sua trajetória artística fora influenciada por diversas e ricas referências, porém, distanciada da interferência e do prestígio do pai famoso.

No texto que segue focaremos a discussão nas duas primeiras questões, quando traremos uma breve biografia dos nossos personagens e analisaremos canções autobiográficas, que mencionam processos de deslocamentos dos dois artistas, buscando perceber também como o Brasil e/ou o brasileiro são pensados em suas canções. Em se tratando de um artigo que impõe limites a extensão da escrita, analisaremos apenas uma música de cada artista, considerada representativa das suas obras.

Para nutrir as discussões da pesquisa serão tomados como aportes teóricos alguns conceitos e reflexões oriundos do pensamento pós-colonial e decolonial, especialmente, formulados na América Latina e no Brasil.

\section{Nossos personagens: Gonzagão e Gonzaguinha}

Todo começo de história requer do/a contador/a o desafio de seduzir o/a leitor/a para as suas minucias, sua grandiosidade e singularidade. Prender a atenção de quem lê ou escuta não é tarefa simples, expectador/a e contador/a precisam seguir juntos/as, trilha adentro do enredo que, como disse Gilberto Gil: deve ser "bordado com a agulha do real nas mãos da fantasia". Essa bela menina, que também pode ser chamada de memória.

No caso específico da história dos Gonzagas de Exu e do Estácio, creio que não será preciso muito esforço, pois sendo essa, uma narrativa tão cheia de paisagens sonoras e afetivas, de imagens que se entrecruzam e se dispersam como num jogo brincado com a lógica das sensibilidades e das circularidades, vos apresentaremos, pois, um enredo urdido por fios de dor e de festa, de partidas e chegadas, de sons, silêncios, escutas, diálogos, estradas e muita peleja. Uma história de alma bem brasileira, ou talvez bem humana. Vamos à ela ${ }^{3}$ !

\subsection{De "tocadorzinho sem futuro" a "Rei do Baião": o improvável percurso de Luiz} Gonzaga do Nascimento

\footnotetext{
${ }^{3}$ Importa esclarecer que as informações presentes nesta primeira seção do artigo são oriundas de muitas fontes pesquisadas. São inúmeros os livros, reportagens, filmes, documentários, teses e dissertações, entrevistas e músicas dos próprios biografados que registram os fatos aqui narrados, desse modo, não será possível referenciar cada informação. Apesar disso, podemos apontar que uma das principais referências utilizadas para compor a apresentação dos dois personagens foi a biografia dupla realizada por Regina Echeverria de título: Gonzaguinha e Gonzagão: uma história brasileira, a qual consideramos um dos materiais mais completos sobre a vida dos dois artistas.
} 
A música na vida desse personagem vem de longe e certamente ainda irá muito longe. Luiz Gonzaga do Nascimento, o famoso Gonzagão, também conhecido como mestre Lua, Lula, ou o "Rei do Baião", nasceu na Fazenda Caiçara, município de Exu, sertão de Pernambuco, no dia 13 de dezembro de 1912. Filho de José Januário dos Santos e Ana Batista de Jesus, mais conhecida como Santana, recebeu um nome completamente diferente dos demais membros da família. Chamou-se "Luiz" porque nasceu no dia de Santa Luzia, "Gonzaga" por sugestão do padre que lhe batizou e era devoto de São Luiz Gonzaga e "do Nascimento" porque nasceu em dezembro, mês do nascimento de Jesus Cristo. A criativa história do seu nome já nos dá uma série de pistas sobre o contexto histórico e geográfico no qual nosso primeiro personagem veio ao mundo.

De origem rural de ambos os lados da família, Luiz Gonzaga teve pouco acesso à educação formal, sua iniciação musical se deu ainda quando menino, observando a mãe nas cantigas de novenas e festas católicas de Exu; mas também e, principalmente, acompanhando o pai que, além de lavrador, consertava e afinava foles de oito baixos e tocava nas festas da região uma sanfona pequena, conhecida como "pé de bode".

Desde a adolescência Luiz se apresentava em festas e "sambas" naquela região, chamando a atenção das mocinhas do lugar. Aos 17 anos apaixona-se pela filha de um fazendeiro próspero na região. A moça que também estava encantada por ele chamava-se Nazarena, era branca, de olhos claros e pertencente a uma família com certo poder aquisitivo, o que claramente impossibilitava um futuro para o namoro. Certo dia, em uma atitude impensada e típica de afirmação da masculinidade naquela região e época, o rapaz que tinha ouvido falar que o fazendeiro havia lhe descomposto por aí. Depois de tomar uns goles, encorajou-se e, em meio a um aglomerado de pessoas, desafiou o fazendeiro a repetir o que havia dito na sua ausência. Por consideração à família do jovem, o coronel Raimundo, decide dispensar o duelo e chama em particular a mãe de Luiz para contar-lhe o ocorrido, ameaçando tomar providências. Indignada e com muita firmeza, Santana arruma os pertences que seriam vendidos na feira e bate em retirada para casa, junto com Luiz. Chegando em casa dá-lhe uma surra e exige que o rapaz desista do descabido propósito. Envergonhado com o acontecido, Luiz foge de casa na madrugada e, sem dinheiro e nem conhecimentos do mundo, vende sua sanfona e consegue chegar em Fortaleza, capital do Ceará. Daí, segundo ele mesmo diz, em 1930, ingressa na escola do pobre, o Exército Brasileiro.

Após servir nove anos no exército, atuando inclusive como corneteiro da tropa, Gonzaga chega ao Rio de Janeiro em 1939, onde investe com muita persistência na carreira 
musical. No início, tocava de tudo e em qualquer lugar, principalmente no Mangue, zona de boemia e prostituição, onde muitos músicos arriscavam o ganha pão. Ali conheceu o músico Henrique Xavier Pinheiro, seu futuro compadre, conhecido no meio artístico como Baiano do Violão e que se tornará um parceiro para a toda a vida. Também foi no Mangue que Gonzaga fora indagado por um grupo de estudantes do Ceará, sobre o fato de não tocar algo da sua terra, do seu "pé de serra". A partir daí o sanfoneiro revisita a memória da infância e retorna dias depois à mesma zona para apresentar o que ele chamou de "vira e mexe". A reação positiva do público ao resfolego da sanfona ligeira foi imediata, no mesmo período apresenta o vira e mexe no show de calouros da Rádio Tupi, coordenado por Ari Barroso, o mais cotado da época, e consegue nota máxima e um bom prêmio em dinheiro.

Nesse ínterim, Luiz Gonzaga passa a perceber que mesmo naquele contexto tão propício à música estrangeira da moda, poderia haver espaço para músicas do seu pé de serra e, aos poucos, começa a assumir um estilo referenciado no sertão nordestino. Chamo a atenção para o termo "aos poucos", tendo em vista que para chegar ao personagem pop consagrado como "Rei do Baião", aclamado inclusive pela grande mídia da época e recordista na venda de discos, primeiro lhe são apresentadas uma série de fronteiras simbólicas que tentam limitar o papel e o seu lugar no mundo. Exigências que se apresentam como padrões culturais e estéticos, próprios de um ambiente comercial que está se consolidando, representado especialmente pela indústria fonográfica e pelo rádio, veículos pautados por uma lógica visivelmente colonialista (capitalista e racista), na qual elege-se uma forma "adequada" de se apresentar para ser aceito pelo público e, consequentemente, atender aos desígnios da lucratividade.

É importante termos em conta que o Rio de Janeiro dos anos 1940, a capital da República, figurava-se simbolicamente como uma espécie de menina dos olhos do Brasil. Um país que se pretende moderno a todo custo, cujas políticas e discursos do Estado Novo objetivavam concretizar uma imagem, para dentro e para fora, associada à lógica da modernidade, da urbanidade e de um progresso que caminhasse em consonância com os "centros" do mundo.

Pensadores/as do campo dos estudos pós-coloniais e mais especialmente teóricos/as associados/as a perspectiva decolonial, a exemplo de Grosfoguel (2008) afirmam que as formas coloniais de dominação não acabaram com o fim das administrações coloniais entre os séculos XIX e XX, continuam presentes nas relações sociais, políticas, epistemológicas e ecológicas, fundadas pelo sistema-mundo capitalista moderno/colonial. O colonialismo, para além de todas as formas de dominação pelas quais é conhecido, tem se perpetuado pelo viés 
de uma dominação cultural que se dá por uma relação extremamente desigual sob a forma de colonialidade do saber e do poder que conduziu à supressão de outras formas de manifestação dos saberes próprios dos povos colonizados (Quijano, 2009).

No caso do Brasil, entendemos que a lógica colonial se reproduz internamente, através de um discurso hegemônico de brasilidade que, a partir do século XX, buscou eleger quais tipos "ideais" de brasileiros/as poderiam representar oficialmente a nação. Desse modo, o falar, o andar, o vestir e consequentemente o cantar, deveriam estar afinados com os padrões de um Brasil moderno e civilizado. Um cantar educado e refinado, valores estéticos que em nada favoreciam o nosso músico de voz grossa, anasalada e carregada de um sotaque indicando que o mesmo provinha de um espaço geoistórico marginal (Mignolo, 2003).

Depois de muitas frustrações e tentativas de conquistar um lugar ao sol carioca Luiz Gonzaga conhece Humberto Teixeira, um advogado cearense de classe média, que morava no Rio de Janeiro há muitos anos e que, como homem branco, letrado e exímio poeta e músico (por paixão), transitava com familiaridade e facilidade pelos seletos circuitos artísticos do Rio. Em parceria com Humberto gravou o primeiro sucesso de público, em 1945, chamado: Lá no meu pé de serra, quando, na voz do próprio Luiz Gonzaga, tematizaram a saudade, a possibilidade de voltar para o sertão, um sertão do bem viver, onde se dança, trabalha, festeja e se tem de tudo. É nesse momento que o sanfoneiro, juntamente com seu mais importante parceiro recria e dissemina o baião, através do rádio, por todo o Brasil e torna-se um dos maiores intérpretes e compositores de sua época. Importante lembrar também que durante a sua carreira o Rei do Baião teve inúmeros e importantes parceiros, sendo Zé Dantas, médico pernambucano, considerado o segundo mais importante parceiro.

Ainda sobre as fronteiras culturais que determinam quem deve estar dentro e quem deve estar fora da cena e pensando como o nosso personagem se viu enredado em tais fronteiras, a pesquisa aponta que um dos elementos que foi fundamental para a afirmação do músico como "Rei do Baião" refere-se a sua vestimenta. Como os demais obstáculos, a opção feita pelo sanfoneiro de eleger como principais signos visuais elementos referenciados no sertão/Nordeste e, especialmente pautados no cangaço lhes custou muito. Como sabemos, nas sociedades modernas, a indumentária constitui um forte social. É possível notar, através das imagens abaixo o processo de composição do seu personagem, que vai de uma vestimenta culturalmente bem-comportada (figura 1); passando a introduzir, em meados dos anos 1940, alguns acessórios que fazem referência ao sertão/Nordeste (figura 2); até a adoção de um figurino totalmente referenciado na construção identitária sertaneja/nordestina, trajando-se por inteiro com símbolos que representam àquela região (figura 03). 


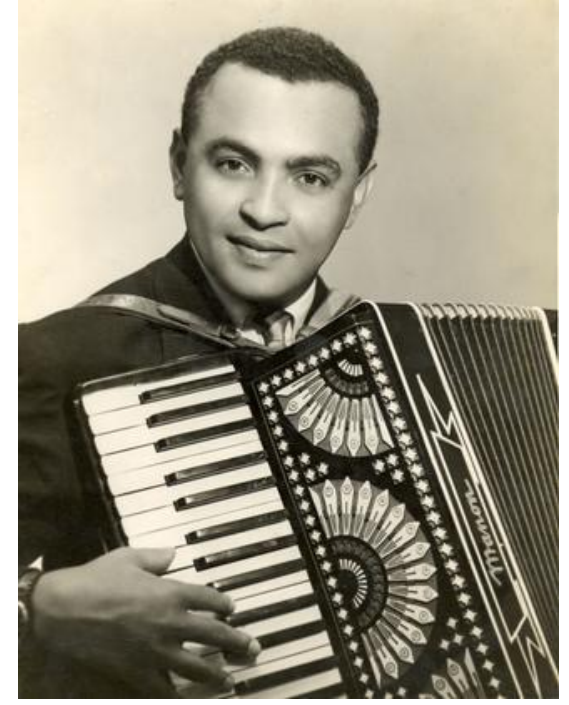

Figura 1 - Luiz Gonzaga no início da carreira. Fonte: Jornal GGN: https://jornalggn.com.br

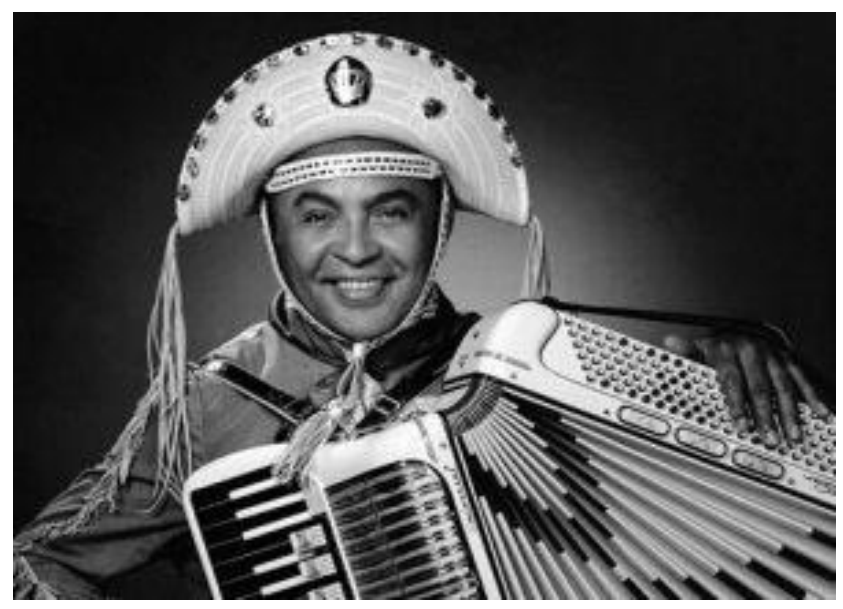

Figura 2 - Luiz Gonzaga por volta de 1945.

Fonte: https://ims.com.br/?s=luiz+gonzaga

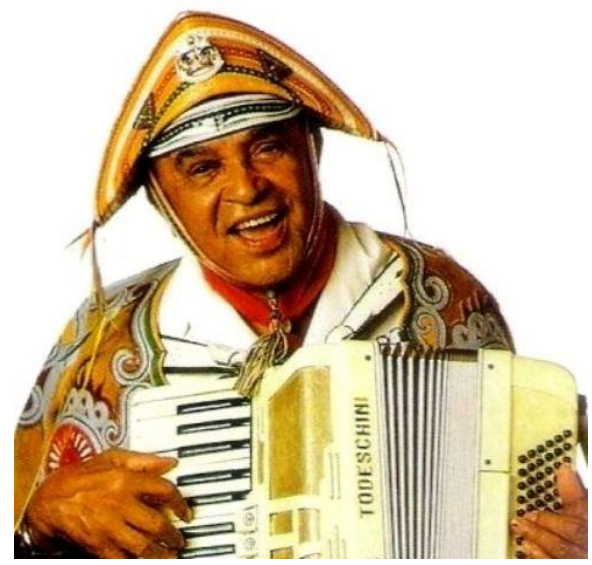

Figura 3 - Luiz Gonzaga por volta dos anos 1980.

Fonte: http://projetogonzagao2012.blogspot.com

Ainda sobre a primeira imagem podemos perceber que, além de seguir uma direção de arte do fotógrafo, o artista do sertão tinha consciência, desde que chegou ao Sudeste, que quanto mais resistisse a adaptar-se à cultura urbana, ou seja, a vestir, falar, comer, dançar, enfim, a se comportar o mais próximo possível das gentes da cidade grande, mais dificuldades teria para conseguir o sucesso. "Uma vez que falar é existir para o outro", como bem nos lembra Frantz Fanon em Pele negra, máscaras brancas, referindo-se ao fenômeno da linguagem no processo de aculturação:

Todo povo colonizado - isto é, todo povo no seio do qual nasceu um complexo de inferioridade devido ao sepultamento de sua originalidade cultural - toma posição diante da linguagem da nação civilizadora, isto é, 
da cultura metropolitana. Quanto mais assimilar os valores culturais da metrópole, mais o colonizado escapará a sua selva (2008, p. 34).

Apesar de Fanon reportar-se mais especificamente ao antilhano em relação ao mundo colonial francês, seu pensamento nos remete diretamente à lógica colonial que se reproduz internamente nos países colonizados, como é o caso do Brasil, cuja região eleita para representar oficialmente o nacional ou o Brasil ideal era o Sul/Sudeste, não era a região de onde Luiz Gonzaga vinha o Norte/Nordeste (Albuquerque Jr, 2005 e Vasconcelos, 2011).

Em um processo de negociação com a cultura hegemônica sudestina, o personagem referenciado no território construído como a "outridade" do Brasil moderno, foi se compondo paulatinamente, ao se definir visualmente, o artista foi afirmando positivamente o seu lugar de origem. Além do uso do gibão, perneiras e chinelos de couro, indumentária própria do vaqueiro do Nordeste brasileiro - pessoa responsável por cuidar do gado -, na cabeça Gonzaga coloca um chapéu também de couro, porém simbolizando outro personagem muito marcante no imaginário nacional: o cangaceiro. Uma figura polêmica que povoa o imaginário nacional, um dos personagens mais presentes no cinema nacional, de quem Gonzaga era fã incondicional, o cangaceiro Lampião. Virgulino Ferreira, o Lampião ou o Rei do Cangaço, como era chamado, foi e ainda é visto por muitos (estudiosos e curiosos) como um herói dos sertões, destemido e ágil, um representante da mais pura valentia do homem do Nordeste e uma vítima da violência entre famílias, muito comum na região e na época. Por outros, especialmente pelo Estado e pela mídia da época, pelos discursos oficiais, era visto como um bandido, facínora cruel e sanguinário, um perigo para a sociedade de bem.

As leituras sobre a caracterização do Rei do Baião podem ser diversas. A percepção trazida por esta pesquisa, considera bastante audaciosa a atitude do artista ao escolher símbolos que, além de não estarem em consonância com as representações de um ideal de Brasil, de algum modo, confrontam tais representações. Poderíamos dizer que o sucesso que obteve até o fim da vida (ora com maior visibilidade, ora ocupando espaços menos menos badalados) sem criar opositores, diz muito da sua capacidade em articular objetividade com maleabilidade, tenacidade e plasticidade. Para conseguir seus desígnios Luiz Gonzaga não costuma "bater de frente" com os cercos que obstruem o seu caminhar, parece sempre utilizarse da tática da sutileza e da negociação (Certeau, 2009); avança quando percebe que há espaço e recua quando a fronteira o impede. Uma tática necessária para sobreviver às imposições de um discurso oficial de brasilidade que não aceita de bom grado a exaltação do sertão e do cangaço. 
A voz, a sanfona, a vestimenta, o modo particular de contar causos e a performance marcante no palco fizeram com que Luiz Gonzaga se transformasse num grande ícone nacional. Para alguns estudiosos, o maior representante de uma identidade regional, a chamada identidade nordestina, pois suas canções mais conhecidas tratam especialmente da seca, da resistência do homem do sertão, da alegria, festas e comidas típicas da região, da saudade do interior do Brasil. Enfim, signos que caracterizam discursivamente uma parte do Brasil que o projeto da nação moderna busca a todo custo negar.

Ao longo da carreira, Gonzaga chegou a gravar 627 músicas em 266 discos. No final da década de 1940 a RCA Vitor, um dado raro entre os grandes artistas do Brasil. Na última década de vida, já doente, Seu Luiz decidiu regressar à terra natal, o Exu. Lá criou o Parque Aza Branca, uma espécie de "lar doce lar" onde viveu até sua morte em 1989. Sua história continua na presença e obra do filho Luiz Gonzaga do Nascimento Júnior, que descortinaremos em seguida, dos seus 04 netos, a maioria envolvida com música e no ecoar das suas canções que até os dias de hoje embalam as noites de São João em todo o Brasil, principalmente na região Nordeste. Luiz Gonzaga continua a representar a alma das festas juninas no interior do Brasil, todos os anos é homenageado pela grande mídia, por grandes marcas de cerveja, pelas escolas infantis, pelos artistas que fazem o São João. A sanfona no Brasil ganhou um novo significado após a sua aparição. É possível que sua obra permaneça viva ainda por longos anos.

\subsection{Do "moleque" Luizinho a Gonzaguinha}

A história de Luiz Gonzaga do Nascimento Júnior, o menino Luizinho e o artista Gonzaguinha, é inteiramente atravessada pela figura do pai e pela música. Uma história dura, difícil e sensível, marcada pela busca e pela compaixão. Por volta de 1944, Luiz Gonzaga (pai) conhece Odaléia Guedes dos Santos, uma jovem artista que, apesar de uma aparência frágil, trazia o expresso desejo de se firmar na vida artística. Segundo Echeverria (2012), Odaléia teria sido a primeira grande paixão de Gonzaga na vida adulta, o casal se conheceu no ambiente noturno de arte, ele tentando a vida como instrumentista e ela dividindo o tempo entre cantar, dançar e compor. Nesse tempo, Odaléia já fazia parte do coro principal de Erasmo Silva, um conhecido cantor de rádio, sendo contratada para gravações também de outros artistas como crooner, pois sua voz se destacava no coro. Simultaneamente trabalhava num dancing como dançarina de aluguel. 
Ao engravidar e possivelmente por saber que tinha ao lado um homem conservador, Odaléia sente que sua carreira pode estar ameaçada e, por isso, desafia o companheiro, e mesmo grávida, volta a trabalhar no dancing. A partir daí, inicia-se uma série de brigas que resultam na separação do casal, que só reata após o nascimento do filho, em setembro de 1945. Luiz Gonzaga registra o menino com seu próprio nome: Luiz Gonzaga do Nascimento Júnior e com a esperança que tudo se ajeite, leva a mulher e o filho para viverem juntos com ele na mesma casa.

Um fato trágico rapidamente vai separar a família: com apenas dois meses de idade Luizinho teve que se afastar da mãe que contraíra tuberculose. Apesar de quase dois anos de tratamento, entre fugas e retornos às casas de saúde, Odaléia veio a falecer aos vinte e dois anos de idade, quando Luiz Gonzaga já estava de casamento marcado com a pernambucana, residente no Rio de Janeiro, Helena Cavalcante que viria a ser sua esposa até o final da vida.

Nessa altura, a carreira de Luiz Gonzaga já havia deslanchado e o sanfoneiro começa a viajar por todo o Brasil, com uma agenda intensa de shows e gravações. Luizinho, então, passa a morar com os padrinhos, Dina e Xavier, numa modesta casa no Morro de São Carlos, por quem é criado como filho. Apesar da ajuda financeira do pai, o menino cresce como mais uma criança pobre do morro, pois o apoio financeiro de Gonzaga em nada mudará a vida dos padrinhos. De um modo geral, podemos dizer que a vida de Gonzaga Jr não foi nem um pouco fácil. Além de ter ficado órfão de uma mãe que mal conheceu, cresceu sem o afeto do pai, ausente por ser um músico viajante, mas também pela rejeição da madrasta que não quis que o menino fosse criado em sua casa. A relação com o pai famoso e distante foi-se dando, através da voz que invadia sua casa pelas ondas do rádio, pois a madrinha escutava programas de rádio durante o dia, e das visitas à casa do pai e da madrasta aos domingos, que aconteciam em virtude da insistência e sabedoria de Dina, que sentia a importância de nutrir aquela relação.

Sua infância, segundo o próprio Gonzaguinha, fora permeada por aventuras, ausências, fugas, desafios e carências, típicas de um menino do morro, ou, como ele mesmo gostava de se auto intitular, de um moleque do morro. Para pensarmos a relação da trajetória desse personagem com sua obra e com o Brasil, é importante ressaltar que, mesmo sendo filho do Rei do Baião, Gonzaguinha cresceu em meio a um ambiente de muita vulnerabilidade.

Os morros cariocas dos anos 1950 não tinham as mesmas características dos morros de hoje em dia, que vivem cercados pelo narcotráfico, seduzindo crianças e jovens ao aparente "dinheiro fácil", e pela presença violenta das milícias - organizações paramilitares que efetuam práticas ilegais sob a alegação de combater o crime, atuam principalmente na 
execução de crianças e jovens negros, moradores das favelas -. Apesar disso, o jogo do bicho já havia se espalhado pelos morros e por ser um jogo proibido pelo Estado, os donos dos pontos recrutavam crianças para transportarem dinheiro, despistando do olhar da polícia. Luizinho que queria ganhar seu dinheiro desde cedo, acabou sendo apanhado pela polícia fazendo esse perigoso serviço.

Não fosse a intervenção dos padrinhos e do pai que o colocou em um colégio interno aos 09 anos de idade, o garoto poderia ter tido um destino infeliz. Mesmo estando no internato a contragosto, Luizinho sempre foi um bom aluno, como já dedilhava algumas canções no violão do padrinho, ganhou do pai o seu próprio instrumento e na introspecção no colégio interno, resolveu se dedicar à música, aperfeiçoando a habilidade com o violão. Aos quatorze anos compôs a primeira canção, gravada pelo pai em 1964, Lembrança da Primavera.

Sua vivência no morro também lhe trouxera muitas aventuras de uma infância livre, com brincadeiras na rua e muito envolvimento com a música, especialmente, com o samba. Luizinho, ainda mais que Luiz Gonzaga, cresceu em um ambiente bastante musical, apesar de não ter convivido com o pai nem com a mãe, ambos cantores/compositores, seu pai adotivo e padrinho, Baiano do Violão, era músico profissional, além de estar sempre tocando violão em casa, instrumento que Gonzaguinha vai adotar como artista. Também sua madrinha, filha de portugueses, ouvia muito fado no rádio, fora que, como disseram os poetas Edson Conceição e Aloísio Silva: "o morro foi feito de samba, de samba pra gente sambar", e era com alguns sambistas que Luizinho convivia e tinha amizade. Em época de carnaval sumia morro acima atrás dos sambistas e só aparecia na hora de dormir, deixando a madrinha aflita. Além de fado e samba, Luizinho ouvia as músicas do pai com atenção e também gostava de ouvir Jamelão, Lupicínio Rodrigues e as cantoras de boleros e músicas românticas.

No período do colégio interno contraiu a mesma doença da mãe, parou os estudos e foi ser cuidado mais uma vez pela madrinha. Depois de curado, resolveu enfrentar seu grande dilema, procurou o pai e propôs morar com ele, mesmo sob o claro desconforto da madrasta. A vida na casa nova foi uma sucessão de dissidências. Passou a dormir no quarto dos fundos, onde passava horas trancado, solitário, tocando, compondo e lendo. Já interessado por política e com expressivo comportamento de adolescente rebelde criado solto no morro, logo começaram os conflitos com o pai, um homem muito simpático e brincalhão na vida pública, mas um pai rígido, austero e ávido por impor suas regras, pois não via com bons olhos o futuro daquele filho malandro carioca, para ele, um desconhecido.

Na Ilha do Governador, onde moravam, Gonzaga Jr começou a dar aulas de violão para alguns jovens para obter algum trocado. Nesse período, já cantava suas composições e 
ganhava algum dinheiro com os direitos autorais da música Lembrança da Primavera. Em 1966 cria o selo "Moleque" para produzir os próprios discos, tudo sem a ajuda do pai e mesmo sem o seu consentimento, pois o sonho de Gonzagão era ver o filho "doutor". O ano 1967 pode ser considerado um marco na vida e na carreira do jovem Gonzaga Jr, pois além de passar no vestibular de Ciências Políticas e Econômicas, como o pai tanto sonhara; conhece o Dr Aluízio Porto Carrero (considerado por Gonzaguinha como seu terceiro pai, guru e futuro sogro), um médico apaixonado por música, poesia e política, que reunia semanalmente em sua casa uma turma jovem universitária para saraus com bom papo, boa música e altas discussões políticas. Ambiente o qual Gonzaguinha logo se identificou, sendo muito bem acolhido.

Nesse universo de liberdade e criação em pleno regime militar, se revelará o grande cantor e compositor Luiz Gonzaga do Nascimento Júnior, nome pelo qual se apresentaria inicialmente como artista. A partir da entusiasmada recepção daquele grupo às suas composições, Gonzaga Jr se lança para o grande público, participando de festivais universitários de música, onde logrou importantes premiações ao lado de Ivan Lins e Aldir Blanc. Com esses parceiros funda o MAU - Movimento Artístico Universitário - um movimento que objetivava abrir espaço no mercado cultural para novos compositores e, por reunir talentos muito promissores, chamam a atenção da TV Globo que, em 1971, os convida para apresentarem o programa Som Livre Exportação. Apesar de ser sucesso de público, o programa dura pouco, pois a censura começa a intervir no conteúdo do programa do início ao fim. Nesse momento, o movimento se desfaz e cada um segue o seu caminho.

Em 1972 assina contrato com a EMI Odeon e grava, inicialmente em um compacto simples, a música Comportamento Geral, um samba de batida leve, mas com forte conteúdo crítico que, em tom de muita ironia, convoca o cidadão brasileiro a refletir sobre o momento político que o Brasil estava vivendo e questiona sua apatia em relação às desigualdades sociais geradas pelo modelo econômico vigente. A partir dessa música que Gonzaguinha ficou conhecido no país inteiro, como a canção fora proibida de ser executada em público pelos órgãos de censura do regime autoritário, os críticos e curiosos ligados à MPB, buscaram conhecer melhor a obra do cantor e compositor, ampliando a venda de discos e tornando-o famoso em todo o Brasil.

Não é possível falar da obra desse artista sem levar em consideração que o início da sua carreira e o alcance do sucesso se deram em um contexto de forte repressão política, instituída a partir do golpe civil-militar de 1964, que levou Gonzaguinha e tantas outras vozes, consideradas dissonantes do amor à pátria, a terem seus processos criativos cerceados. 
Muito brevemente falando, o Brasil viveu entre os anos de 1964 e 1985 sob um duro regime ditatorial comandado pelos militares. Em março de 1964, civis e militares se uniram com o apoio da Igreja Católica e do governo norte-americano com o objetivo de derrubar o presidente João Goulart, que prometia realizar reformas sociais, políticas e econômicas, visando à diminuição das desigualdades e ao aprimoramento do processo democrático. Tais reformas foram vistas pelas elites conservadoras como o perigo da implantação do comunismo no país e, através de um golpe de Estado, planejado por forças políticas de dentro e de fora do país, depuseram o governo e promoveram a subida dos militares ao poder, instaurando um regime de exceção, fechando o Congresso Nacional e suspendendo os direitos civis e as eleições diretas, durante 21 anos (Napolitano, 2010).

Esse período, caracterizado por um ostensivo exercício de silenciamento, deixou marcas profundas na sociedade brasileira e, apesar de uma ampla produção intelectual e artística da época ou sobre a época, o fantasma da ditadura continua a nos assombrar nesse momento. Ciclicamente os fatos e o enredo, a exemplo do perigo comunista (tão propagado pelos Estados Unidos durante a Guerra Fria e o susto com a Revolução Cubana) e da defesa da família e da moral, se repetem no contexto atual, tal e qual na década de 1960, porém difundidos com mecanismos mais sofisticados e velozes.

Como muitos artistas da época, Gonzaga Jr direcionou grande parte da sua obra a uma posição de resistência ao regime militar e de crítica à política vigente no país. Segundo Severiano e Mello (1998), ao lado de Chico Buarque de Hollanda e Taiguara, Gonzaguinha estaria entre os compositores mais perseguidos pela censura durante a ditadura, tendo em média $70 \%$ de suas canções censuradas. Para gravar dezoito canções nos dois primeiros álbuns, Gonzaguinha chegou a submeter 72 músicas à censura, sendo 54 vetadas. O jornalista e crítico musical Tárik de Souza afirma que Gonzaguinha foi o artista "[...] que mais problemas teve com a censura nos anos 70", recebendo a "[...] etiqueta de maldito" (BAHIANA, 1976, p. 26).

Apesar de ter encontrado fronteiras diversas em sua trajetória de vida e de arte, algumas delas muito próximas as que seu pai enfrentou, Gonzaguinha viveu um processo de silenciamento da sua expressão que marcou para todo o sempre sua trajetória. Mesmo sem sofrer violência física, como muitos outros companheiros perseguidos da sua época, a forma de censura a voz do artista, lhe alcançou sem brechas e com consequências duras a uma possível desobediência, pois a fronteira que demarca até onde se pode ir, foi erigida por um órgão oficial de um Estado autoritário, representado pelo DOPS - Departamento de Ordem Política e Social - que tinha o poder de definir o que pode ser dito e o que deve ser calado. 
As formas de resistência que visavam driblar a censura nesse período eram diversificadas e às vezes muito sofisticadas. Ao mencionar sua relação com a repressão oficial, Gonzaguinha demonstra usar da tática da malandragem do morro, ao sugerir que é preciso ter calma, esperar a sua hora e driblar o adversário com sutil maestria. Em uma de suas canções, faz o seguinte enunciado: "no campo do adversário é bom jogar com muita calma, procurando pela brecha pra poder ganhar". Apesar de utilizar de algumas táticas sutis como o pai, para deslocar fronteiras e acessar espaços pouco propícios a escutar sua voz, Gonzaguinha caminhou mais pelo modus operandi "bater de frente", mesmo em meio a um regime duro, não se furtou a fazer discursos críticos em relação à ditadura.

O fato de ser um artista que não fazia concessões ao mercado, que não dava autógrafos e que praticamente só gravava músicas autorais, além da postura pouco simpática com a mídia, levou Gonzaguinha a ganhar o apelido de "cantor rancor", sendo considerado, durante muito tempo, pela mídia (ver figura 4) como hostil, antipático, antipatriota, um poeta maldito. Durante toda a carreira, mesmo passando a cantar músicas leves e românticas, nunca abriu mão de uma postura comprometida com a vida e com o país. Podemos dizer que ele representa uma dessas vozes rebeldes que se recusou a calar diante da censura, não se submeteu ao jogo da mídia e pagou um preço alto por isso. Abaixo uma reportagem de 1980, do jornal $O$ Estado de São Paulo, em que, sem rodeios dispara-se uma série de adjetivos pejorativos para se referir ao cantor.

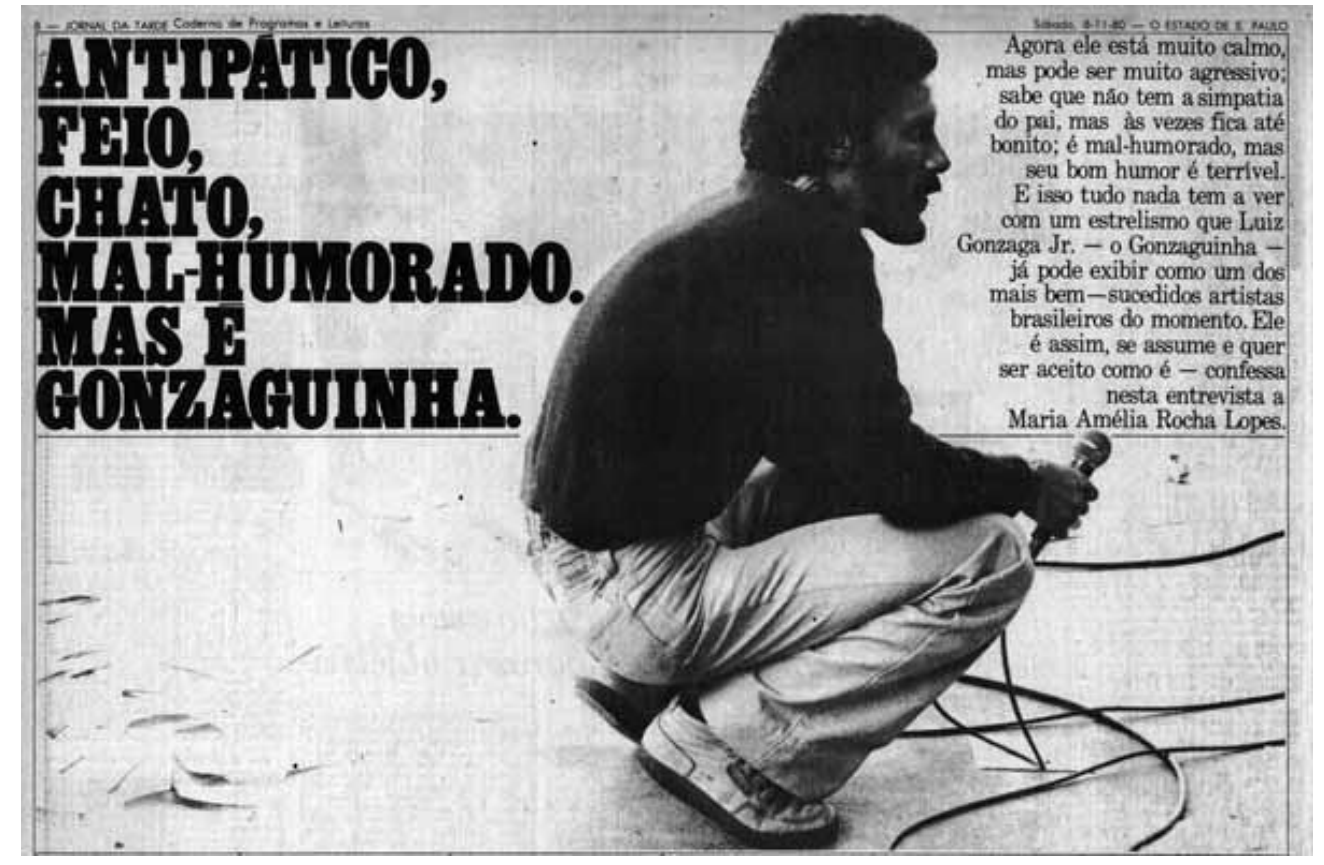

Figura 4 - Reportagem do Jornal O Estado de São Paulo sobre Gonzaguinha, 1980.

Fonte: http://www.diariodomeiodomundo.com.br/2012/12/gonzaguinha-um-pouco-da-trajetoria-de.html 
Apesar de ser lembrado até os dias de hoje como uma importante voz de resistência à ditadura, Gonzaguinha ficou mais conhecido do grande público e podemos dizer que alcançou o auge do sucesso com grande venda de discos, no final da década de 1970, quando ao lançar músicas românticas aboleiradas, a exemplo de Explode Coração e Grito de Alerta, gravadas por Maria Bethânia, posicionando-se inclusive entre os dez compositores mais importantes daquele período e que mais ganharam dinheiro com direitos autorais. Mesmo não aderindo à lógica implacável do capital para alcançar a fama, ainda nos anos 1970, de proletário da arte alçou voo e adentrou o cobiçado panteão dos grandes nomes da Música Popular Brasileira.

Ao longo da carreira gravou cerca de 35 discos, chegando a ganhar importantes prêmios (a exemplo dos prêmios: Sharp de Música em 1988 e do prêmio de melhor música na categoria MPB, no II Prêmio da Musica Brasileira, em 1989) e sendo gravado por intérpretes de grande sucesso, a exemplo de Elis Regina, Simone, Maria Bethânia, Cauby Peixoto, entre outros. Mostrou-se um poeta sensível e em estado permanente de indignação. Viveu os últimos dez anos de sua vida em Belo Horizonte - Minas Gerais. Segundo depoimento de amigos próximos, essa fase da vida de Gonzaguinha foi de calmaria e felicidade. Além de conseguir o tão sonhado encontro com o pai, pôde estar mais tranquilo financeiramente, vivenciar a paternidade com dedicação total, esteve a compor quase que diariamente.

Mesmo tendo se relacionado a todo tempo com um mercado cultural, que possivelmente vislumbrou os ganhos em associá-lo a imagem e a fama do pai, Luiz Gonzaga Júnior surge no cenário nacional de maneira desassociada da figura artística do pai, trilhando seu destino, desde muito cedo, de forma independente. Apesar de encontrar por seu caminho incontáveis barreiras, consegue, com trabalho e sagacidade, utilizando táticas ou estratégias distintas do pai, imprimir sua marca na história da música brasileira. Gonzaguinha trouxe para o Brasil uma poética muito própria e uma forma bastante singular de estar na vida. Sua obra é consideravelmente vasta e profunda tanto na forma quanto no conteúdo, tematiza o amor, questiona o sistema, fala de esperança, de masculinidades, da grandeza da cultura infantil, da sua própria vida e sempre do Brasil.

Na última década de vida de ambos, pai e filho se aproximam, e, a convite do filho, realizam uma turnê que mudou para sempre a relação dura e delicada que durou quase uma vida. No show Vida de Viajante descobrem afinidades, afetos, diferenças, respeito, confissões e amizade. O desejado encontro acontece e ao que parece a necessidade de estarem juntos foi tanta que, em um intervalo de menos de dois anos, morre o pai (em 1989, de problemas de saúde) com 76 anos e logo em seguida o filho (em 1991, de acidente de carro) aos 45 anos. 


\section{Músicas autobiográficas do "Rei do Baião" e do "príncipe Moleque"}

\subsection{Regressei!}

De Luiz Gonzaga apresentaremos o baião Respeita Januário, composto por ele em parceria com Humberto Teixeira e lançado em 1950. Em linhas gerais, a canção retrata a volta do artista 16 anos depois de partir da casa dos pais, no sertão do Araripe. Segundo relato do próprio Gonzaga, seu desejo era retornar a sua terra apenas depois de "vencer na vida", nesse caso, ficar famoso.

Já com a vida financeira estável, fazendo sucesso em todo o Brasil e dirigindo um automóvel de luxo para a época, Luiz chega em sua antiga casa, no povoado de Caiçara, propositalmente a meia noite. Queria fazer uma surpresa aos pais e aos irmãos. Essa história é muito conhecida de todos os amantes da sua obra, pois antes de iniciar a canção, Gonzaga narra com detalhes esse acontecimento, como poderemos ler mais abaixo.

Chamamos a atenção para o fato de que a leitura, especialmente, no que se refere a essa canção, não tem o mesmo efeito da audição, visto que a narrativa inicial se dá no sentido de uma contação de causo - modalidade de narrativa oral muito comum nas sociedades tradicionais com menos acesso ao letramento-, com exclamações, risos e espantos. Emoções transmitidas ao público, que podem ser lidas como técnicas típicas de um bom contador de histórias. Incluiremos no final do texto o Link de acesso para escuta da música.

Iniciaremos com a narrativa oral que é feita como introdução da música e em seguida apresentaremos a letra da música. É importante explicitar que serão utilizadas palavras escritas em um padrão não convencional da língua portuguesa, visto que tal mecanismo foi usado pelos compositores Luiz Gonzaga e Humberto Teixeira, provavelmente como estratégia de aproximação do artista com um determinado tipo de público. O texto apresentado abaixo se refere a uma gravação presente no disco Еu е теи pai, de 1979 (RCA).

Esse negócio de matar gente no sertão já foi trabaio mais manero, menos pra eu, quis matar um homem, me lasquei, levei uma surra tão danada, uma surra caprichada por meu pai e minha mãe, que eu arribei de casa, dezoito anos incompleto. 1930, ingressei nas forças, revolução como o diabo, tiro como o diabo, nunca dei nenhum, eu queria ser era artista, hahai... ingressei na RCA, onde estou até hoje, graças a Deus. Aí eu já era artista, artista do Nordeste, meu sonho. Comecei a sentir saudade de casa. Home, pelo cartaz que eu tenho eu acho que já dá pra voltar. Eu quero dar uma surpresa danada a meu pai, a surpresa vai ser tão grande que ele nunca mais vai esquecer na vida dele. Regressei. Cheguei em casa de madrugada, tô ali, naquela madrugada sertaneja, frente a frente com a minha casa, chamei: - Ô de casa, (ninguém responde) ô de casa (ninguém responde), me lembrei do pré-fixo: louvado seja nosso Senhor Jesus Cristo.

- Para sempre seja Deus louvado! - É seu Januário?

- Sim senhor, 
Tô vindo do Rio de Janeiro, seu Januário, trago um recado pro senhor, é do fio do senhor, mandou até uma coisinha pra lhe entregar. Tô morrendo de sede, quando vim de lá traga um copo de água pra mim, copo não, traga mesmo um cofo.

Aha! fiquei olhando pela greta da janela, aí vi o véi acender o candeeiro, escutei o timbungado do caneco no fundo do pote, no fundo do pote, lá no fundo: "tibungo", haha, lá vem o véi pelo corredor. Caneco numa mão, o candeeiro na outra, chegou mesmo na janela que eu tava. Arriou o cofo d'água no batente da janela, tirou a tramela, abriu a janela em cima de mim. Aí eu senti o cheiro dele, aquele, aquele cheiro antigo, aquele cheiro meu, ha, ele encandeou-se, levantou o candeeiro acima da cabeça, me interrogou: - Quem é o senhor? - Luiz Gonzaga, seu filho.

- Isso é hora de você chegar em casa? Seu coooooorno. Santana, Gonzaga chegou. Viva a Deus.... a meninada: Êeeeeeeeee! Menino como o diabo, irmão que eu não conhecia, haha, aí ninguém dormiu mais. De manhã cedo a casa já tava cheia de gente. Aí eu digo, agora eu vou fazer bonito, vou cantar pra esse povo. Desembanhei a sanfona e mandei brasa. Quando eu pensei que tava agradando, Raimundo Jacó gritou lá no meio povo: Luiz, respeita Januário, moleque, Hahaaaaa...

(começa a música): Quando eu voltei lá no sertão Eu quis mangar de Januário Com meu fole prateado

Só de baixo, cento e vinte, botão preto bem juntinho Como nêgo empareado Mas antes de fazer bonito de passagem por Granito Foram logo me dizendo:

"De Taboca à Rancharia, de Salgueiro à Bodocó, Januário é o maior!"

E foi aí que me falou meio zangado o véi Jacó:

Luiz, respeita Januário

Luiz, respeita Januário

Luiz, tu pode ser famoso, mas teu pai é mais tinhoso

E com ele ninguém vai, Luiz Respeita os oito baixo do teu pai! Respeita os oito baixo do teu pai!

A escolha dessa música, dentre tantas do mestre Lua que podemos considerar autobiográficas, se justifica primeiro por retratar um episódio que marcou a vida do sanfoneiro e que representa o sonho de inúmeros migrantes: o retorno à sua casa, ao lugar de origem e, ainda mais, o retorno a sua terra como uma referência de sucesso. Como um sujeito admirado por todos pelo fato de ter tido a coragem de partir sem nenhuma garantia prévia e ter conseguido "dar certo na vida". No caso do nosso personagem, a volta à sua terra - como um artista de sucesso em nível nacional - não pode ser considerada um fato qualquer, mediante o contexto no qual essa história se passa.

É importante termos em conta que o interior do Brasil e ainda mais o interior do Nordeste nos anos 1930/1940 apresentava uma realidade de extrema escassez. Além das prolongadas secas que assolavam a vida do sertanejo, obrigando-o a migrar de tempos em tempos, notava-se uma total ausência dos serviços básicos prestados pelo Estado; as famílias eram numerosas; a mortalidade infantil alta, havia muita desigualdade, e o acesso à educação formal muito difícil. Tudo isso reduzia enormemente as possibilidades de ascensão econômica e social da população mais pobre, de modo que o sonho de muitos sertanejos era migrar, principalmente, para São Paulo, sinônimo de trabalho e possibilidade de ascensão, ou para o 
Rio de Janeiro, sinônimo de modernidade.

Esse dado é tão forte no imaginário sobre o sertanejo que sempre nos deparamos com personagens da literatura e do cinema que migram para as grandes cidades e quase sempre tem seu sonho frustrado, devido as inúmeras dificuldades que encontram nas metrópoles. No caso do nosso personagem a volta à casa dos pais é sinônimo de orgulho e alegria, volta como um homem de sucesso, um verdadeiro pop star. Artista de renome nacional com grande presença no rádio, admirado por todos, portando uma sanfona de 120 baixos. Torna-se o orgulho nem só da família, mas de toda a cidade e mesmo do estado de Pernambuco. Não há dúvidas: Luiz Gonzaga regressou como um verdadeiro Rei, o Rei do Baião.

Como bom sertanejo que era, demonstra que, apesar de todo seu "cartaz" e da sanfona de última geração, não esquecera de honrar o que aprendeu com o velho Januário na sanfoninha de 08 baixos. Mesmo, que a letra da canção afirme que o sanfoneiro ao voltar para o sertão quis mangar (zombar) de Januário com seu fole prateado, o fato de mencionar a fama do pai na região e a repreensão recebida do velho Jacó quando diz: Luiz, respeita Januário. Luiz, tu pode ser famoso, mas teu pai é mais tinhoso e com ele ninguém vai, Luiz respeita os oito baixo do teu pai, nos leva a interpretar a música como uma grande homenagem ao pai. Um reconhecimento da importância e da influência musical que o velho teve em sua vida.

Um segundo aspecto que justifica a escolha de Respeita Januário é que esse baião poderia representar uma espécie de síntese do que significou emblematicamente a obra de Luiz Gonzaga para o Brasil. Apesar da canção fazer referência a história de vida do cantor, e mais especificamente à sua condição de migrante, podendo ser lida como uma produção autobiográfica, também nos leva a pensar como o Brasil é apresentado pelo sanfoneiro. A grande maioria das suas canções traz em seu conteúdo (letra) e na sua forma (ritmo, instrumentos) o Sertão/Nordeste: as comidas, as festas, os costumes, as dores, os personagens e as vozes que representam essa região. Pode-se afirmar que a principal marca do Gonzagão é apresentar o Sertão/Nordeste para o resto do Brasil e para o mundo.

Desse modo, Luiz Gonzaga é, ele próprio, a representação de um viés de brasilidade que o discurso oficial não dá conta ou não quer ver representado. Falo do Brasil sertanejo, rural, nordestino, que aos olhos dos desenvolvimentistas do Sul/Sudeste de ontem e de hoje poderia ser considerado como resíduo, um espaço geográfico circunscrito ao passado e que diante do fetiche da modernidade continua a representar o atraso, a ignorância e a pobreza.

A história da construção identitária da brasilidade que envolve o conflito ou a divisão regional entre Sudeste e Nordeste é uma longa história que não será possível ser abordada 
nesse breve artigo, para um maior aprofundamento da discussão sugiro verificar Albuquerque Jr (2005) e Vasconcelos (2011). No momento, objetivamos chamar a atenção do/a leitor/a para a importância da aparição de uma voz como a de Luiz Gonzaga no cenário nacional, pautando e positivando um espaço geográfico e seus costumes, cuja imagem é sistematicamente degradada por parte das elites e da grande mídia.

A presença do cantor nordestino, negro e semianalfabeto, vestido de cangaceiro e exaltando os saberes e a cultura do seu sertão em plena década de 1940, nos leva a crer que sua presença e obra estão em dissonância com o projeto de Brasil desse período. É interessante pensar que sua voz é projetada a partir do Rio de Janeiro - a capital federal da época -, para o resto do Brasil; esses dados nos dizem que sua atuação destacada no cenário cultural brasileiro do século XX pode ser lida como um discurso insubmisso ou um "contradiscurso", em relação aos discursos de modernização do país.

É no retorno à sua origem rural e referenciando-se esteticamente no Sertão/Nordeste que Gonzaga encontra o seu lugar na música e na cultura brasileira e torna-se um importante representante de uma grande parcela da população brasileira. Sua condição de migrante é a condição de inúmeros brasileiros pobres da época, inclusive do Presidente Luís Inácio Lula da Silva, que chegou a São Paulo junto com a família, em um pau-de-arara - caminhão com cobertura de lona-, depois de longos dias de viagem.

Outro aspecto que chama a atenção nesta canção e que podemos apontar como uma marca desse artista é o recurso da contação de causo. Em diversas canções, a exemplo de Karolina com $K$ e da memorável Samarica Parteira, Luiz Gonzaga se expande pelo palco, muda de entonação, utiliza pausas e onomatopeias, apresenta códigos muito próprios da sua região e leva o público ao delírio. Poderia dizer que Gonzaga é um performer musical, para utilizar uma palavra mais moderna, ou um lendário griô do sertão, pois consegue com maestria conectar sua música com um traço muito presente nas sociedades de tradição oral, que não se limitam à lógica racionalista do letramento e que têm na palavra a força da sua expressão cultural.

O Brasil tem uma cultura fortemente oral, e em se tratando de comunidades rurais, isso se apresenta de maneira ainda mais marcante. De acordo com Paul Zumthor (2000), a sobrevivência de grande parte das manifestações "populares" da cultura brasileira se deve especialmente ao uso da linguagem oral.

Certamente ainda há muito o que explorar na análise da canção Respeita Januário, a exemplo da menção a personagens reais, das especificidades do contexto daquela região, do que essa viagem de volta lhe trouxera de novo para o seu repertório enquanto artista em 
trânsito, mas como o formato do texto requer síntese, deixemos para prosear mais na feitura da tese.

\section{2. "É que o mundo é que é meu lugar"!}

Para pensar como a trajetória desse artista aparece em sua obra e como o mesmo desloca fronteiras que intencionam limitar sua atuação e censurar sua expressão, escolhemos o samba Com a perna no mundo, de autoria do próprio compositor, gravada no disco Gonzaguinha da vida, de 1979. A canção trata de um momento importante da sua vida, quando, aos 16 anos de idade, depois de passar por um longo período de reclusão, por causa do tratamento da tuberculose, decide descer o morro e ir morar com o pai.

Tal canção certamente traduz algumas das principais características do cantor e compositor, sendo uma delas a profunda sensibilidade nas letras que compõe, expressa através de uma forma poética que consegue aproximar realidade concreta, e às vezes dura, com alegorias festivas e linguagem metafórica. Outra marca do artista é que, apesar de aparentar para o público um distanciamento constante, por seu jeito pouco carismático com os fãs e com a mídia, Gonzaguinha desde o início da carreira nunca teve problema em se desnudar através da veia poética, da música que produziu. Diversas de suas canções tratam de experiências e sentimentos pessoais, seus medos, angústias e sonhos, de modo que não foi fácil eleger qual música autobiográfica analisar. Vamos à escolhida:

Com a Perna no Mundo

Acreditava na vida, na alegria de ser Nas coisas do coração, nas mãos um muito fazer

Sentava bem lá no alto, pivete olhando a cidade Sentindo o cheiro do asfalto, desceu por necessidade

Ô Dina, teu menino desceu o São Carlos Pegou um sonho e partiu Pensava que era um guerreiro Com terras e gentes a conquistar Havia um fogo em seus olhos Um fogo de não se apagar

Diz lá pra Dina que eu volto, que seu guri não fugiu Só quis saber como é, qual é, perna no mundo sumiu

E hoje, depois de tantas batalhas, A lama dos sapatos é a medalha Que ele tem pra mostrar 
ô ô ô ê é, o moleque acabou de chegar ô $\hat{o}$ ô ê é á, nessa cama é que eu quero sonhar ô ô $\hat{o}$ ê á, amanhã boto a perna no mundo ô ô ô ê é á, é que o mundo é que é meu lugar

Tendo em vista que forma e conteúdo não devem ser vistos como coisas estanques, ainda mais em se tratando do objeto canção, que é composto por muitos elementos (melodia, ritmo, letra, arranjo, etc), também recomendamos a/o leitor/a a escuta deste samba de Gonzaguinha (ver link ao final do texto), pois esta é uma música de ritmo contagiante e alegre, dançante como todo samba. Apesar do ritmo festivo e de uma poética sublimada, a canção trata de um episódio crivado pela dor, a dor da rejeição do pai, dor esta que acompanhou Gonzaguinha durante a maior parte da sua vida.

Aos 16 anos Gonzaguinha decide sair de casa. Depois de curado de uma tuberculose que certamente o levou a refletir sobre a vida e já com pretensões de seguir a carreira artística, o menino de São Carlos, sente o cheiro do asfalto, e por necessidades diversas, desce o morro. Pelo menos três questões nos chamam a atenção em um primeiro momento de análise: a primeira, refere-se a episódios que aparecem, de algum modo, também na música Respeita Januário, acima analisada. Uma delas tem a ver com a coincidência da idade em que pai e filho se veem em situação de (des)encontro com a família. O pai, aos 17 anos saiu de casa em virtude de um episódio de conflito com a família, seguiu vida afora, enfrentando desafios que o mundo lhe apresentou. O filho Gonzaguinha, saiu da casa dos padrinhos, Dina e Xavier, aos 16 anos, não por um conflito com estes, mas pelo desejo de um encontro com o pai, um pai desconhecido e severo, que provavelmente representava para ele um grande desafio.

A saída de casa aparece na música, por vezes, de forma metafórica e, por vezes, em linguagem direta. Ao mencionar o "cheiro" do asfalto, ato sensorial também trazido por Gonzagão na música Respeita Januário para descrever o reencontro com o pai, Gonzaga Jr traz o sentido simbólico da palavra. Sentir o cheiro do asfalto significa sentir um chamado, um desejo de descer o morro e encarar a vida na cidade, junto ao pai e à madrasta, e assim começar uma vida nova, longe do colo de Dina. Ainda tratando da saída de casa, Gonzaguinha utiliza também uma linguagem direta, menciona mais de uma vez a mãe Dina, e como em forma de diálogo, justifica sua decisão na frase: Ô Dina, teu menino desceu o São Carlos, (...) desceu por necessidade..., ou como que se desculpando, no trecho: Diz lá pra Dina que eu volto, que seu guri não fugiu, só quis saber como é, qual é, perna no mundo sumiu. 
A segunda questão aponta como o autor/compositor se apresenta para o público em diferentes versos da canção; usando a sensibilidade poética, descreve como ele próprio se vê. Aqui podemos afirmar que o compositor exercita o que Alessandro Portelli (2010) chamou de construção de si. Assim como o referido autor, também penso que podemos compreender uma história de vida de várias formas, através dos artefatos verbais presentes na autopercepção do narrador e no encontro entre este e o pesquisador que se dispõe a interpretar o que acessa no tocante à fala, ao texto ou à música do sujeito pesquisado.

No caso estudado o cantor traz essa autoconstrução na perspectiva da criança que foi. $\mathrm{Na}$ primeira estrofe fala das crenças e práticas enquanto menino: acreditava na vida, na alegria de ser, nas coisas do coração, nas mãos um muito fazer. Sentava bem lá no alto, pivete olhando a cidade; na terceira estrofe expressa sonhos e projeções do passado: pensava que era um guerreiro, com terras e gentes a conquistar, havia um fogo em seus olhos, um fogo de não se apagar... Ao utilizar o pronome "seu" e não "meu" deixa claro que está falando da sua criança, da criança que foi, que viveu no morro e de como ele, o adulto Gonzaguinha, consegue olhar para trás e enxergar essa criança. Apresenta-se como um menino sonhador, que se deixa atravessar pela imaginação e pela busca, um menino livre que se move morro adentro e morro acima, vê a beleza da cidade do Rio de Janeiro lá do alto, brinca, fantasia, mas também já percebe a necessidade da luta diária, a dureza da vida do trabalhador, da dona de casa (a madrinha/mãe), do artista pobre (o padrinho, compositores do morro). Um moleque do morro que sabe o que quer e sabe que tem que lutar por isso com fogo nos olhos.

Ainda sobre o quesito infância percebe-se que durante toda a música o cantor se refere à sua criança, utilizando quatro diferentes formas de expressão: pivete olhando a cidade; teu menino desceu o São Carlos; que seu guri não fugiu; o moleque acabou de chegar. Convém dizer que os termos "pivete" e "moleque" no Brasil têm uma conotação pejorativa. São usados geralmente para sugerir que um menino é malcomportado, bagunceiro, menino de rua, menino do morro, da favela, ou até mesmo para se referir a um menino que furta.

Ao consultar dois dicionários da língua portuguesa, sendo o dicionário online Aurélio e o dicionário online de Português, encontramos as seguintes definições para a palavra "moleque": garoto muito traquinas; Menino muito sapeca e levado. Pessoa que não merece confiança; quem é canalha; vil. Pessoa que gosta de fazer graça. Menino que vive na rua; menino de rua. Menino jovem, de pouca idade; garoto. Para a palavra "pivete" encontrei os seguintes sentidos, ainda mais depreciativos: Criança ladina, com pretensões a pessoa crescida. Menino que rouba e que vive na rua. Criança ladina com ares de adulto. 
Menino(a) ladrão, ou que anda com gatunos, auxiliando-os. Como vimos, os termos escolhidos por Gonzaguinha para se auto definir na infância não são nem um pouco bem vistos pelas instituições que representam o pensamento da sociedade convencional brasileira.

Na medida em que Gonzaga Jr adota em toda a sua carreira o codinome "moleque" termo inclusive escolhido por ele para nomear o selo da gravadora independente que criou, e também para intitular a música com a qual concorreu no Festival da Record de 1973 e ainda para denominar o LP lançado em 1977 (Moleque Gonzaguinha) -, certamente objetiva firmar uma postura de transgressão e rebeldia ante a sociedade na qual vive, considerada por ele, opressora e conservadora.

Ao contrário do pai, que nunca bateu de frente com seus opositores, Gonzaguinha manifesta abertamente insatisfação e perplexidade em relação ao contexto de repressão do qual é vítima direta, e acaba por transformar a expressão contestatória em uma das marcas da sua obra. O que considero relevante no uso do termo "moleque" é também a forma como o cantor ressignifica o conceito, e com toda nobreza, afinal é filho de um Rei, consegue colocar leveza e poesia na sua molecagem ao traduzir seu passado como: um pé no chão e um sabiá, e como uma eterna criança "moleque", mostrar-se totalmente aberto ao presente representado por uma: porta aberta, e ao futuro, que na sua ótica, é o que virá, mas e daí?

A partir dessas reflexões, penso que Gonzaguinha, de outro modo, também pode ser considerado uma voz dissonante da brasilidade oficial e bem-comportada. No momento atual em que a pesquisa se encontra, tais análises aparecem como suposições, hipóteses, desconfianças, por isso, optamos por não finalizar esse texto com conclusões, certezas. Nesse itinerário, sentimo-nos instigadas a levantar novas perguntas e a travar novos debates.

\section{Referências:}

ALBUQUERQUE Jr., Durval Muniz de. A Invenção do Nordeste e outras artes. São Paulo: Cortez. 2005.

BAHIANA, A. M. Gonzaguinha termina mais um LP e perde o sono. Jornal de Ibraim Sued. Rio de Janeiro: 01 mai. 1976.

CERTEAU, Michel de. A invenção do cotidiano: artes de fazer. Rio de Janeiro: Vozes, 2009.

Dicionário Aurélio Online. Disponível em: https://dicionariodoaurelio.com. Acesso em 22 janeiro 2019. 
Dicionário Online de Português. Disponível em: https://www.dicio.com.br. Acesso em 22 janeiro 2019.

ECHEVERRIA, Regina. Gonzaguinha e Gonzagão: uma história brasileira. São Paulo: Ediouro, 2012.

FANON, Frantz. Pele negra, máscaras brancas. Salvador: Edufba, 2008.

GROSFOGUEL, Rámon. "Para descolonizar os estudos de economia política e os estudos pós-coloniais: transmodernidade, pensamento de fronteira e colonialidade global". Revista Crítica de Ciências Sociais, 2008, n.80, p.115-147.

MIGNOLO, Walter D. Histórias locais/Projetos globais: colonialidade, saberes subalternos e pensamento liminar. Belo Horizonte: Editora UFMG (Humanitas), 2003.

NAPOLITANO, Marcos. História \& Música. História cultural da música popular. 2 ed. Belo horizonte: Autêntica. 2005.

. Seguindo a canção: engajamento político e indústria cultural na MPB (19591969). São Paulo: Annablume/FAPESP, 2010.

PORTELLI, Alessandro. Ensaios de história oral. São Paulo: Letra e voz, 2010.

QUIJANO, Aníbal. Colonialidade do Poder e Classificação Social. In: SANTOS, Boaventura de Souza e MENEZES, Maria Paula (orgs). Epistemologias do Sul. Coimbra: Edições Almedina. SA. 2009.

SEVERIANO, Jairo; MELlO, Zuza H. de. A canção no tempo: 85 anos de música brasileiras. Vol. 02, 1958 - 1985. São Paulo: Ed 34, 1998.

VASCONCELOS, Cláudia P. Ser-Tão Baiano: o lugar da sertanidade na configuração da identidade baiana. Salvador: EDUFBA, 2011.

ZUMTHOR, Paul. A letra e a voz. São Paulo: Companhia das Letras, 2000.

\section{Músicas:}

1. Respeita Januário (Luiz Gonzaga e Humberto Teixeira). LP Eu e meu pai, RCA, 1979. Disponível em: https://www.youtube.com/watch?v=PgSAp-dNAJE versão ao vivo da canção intercalada com o causo, transmitida pela TV Record. Ou disponível em: https://www.youtube.com/watch? v=U1eyerKABr0 versão gravada em disco em um show realizado em 1979, no Teatro Tereza Raquel, no Rio de Janeiro.

2. Com a perna no mundo (Gonzaguinha). LP Gonzaguinha da vida, EMI/Odeon, 1979. Disponível em: https://www.youtube.com/watch?v=PtE48yc_AO0 